\title{
Back-up Perlindungan Relay Jarak Zona Kedua oleh Directional Overcurrent Relays dengan Combined Curves
}

\author{
Ariq Arsya Nanda, Margo Pujiantara, Ardyono Priyadi \\ Jurusan Teknik Elektro, Fakultas Teknologi Industri, Institut Teknologi Sepuluh Nopember (ITS) \\ J1. Arief Rahman Hakim, Surabaya 60111 Indonesia \\ e-mail: ariqarsya@gmail.com
}

\begin{abstract}
Abstrak-Dalam makalah ini, pendekatan baru untuk simultan pengaturan jarak dan relay arus lebih terarah. Ketika skema perlindungan garis terdiri dari relay jarak dan relay arus lebih terarah pengaturan relay harus dihitung mengingat kedua relay. Terpisah perhitungan estafet akan menyebabkan hilangnya selektivitas. Jika kedua zona waktu pengaturan adalah tetap, penentuan otomatis dari pengaturan bisa menyebabkan situasi nonlayak, menunjukkan kemustahilan menemukan satu set selektif pengaturan. Jadi zona waktu kedua harus diubah secara manual sampai masalah optimasi layak. Dalam metode ini, yang terbaik pengaturan untuk zona kedua yang menjamin selektivitas bisa lebih besar dari pengaturan klasik, begitu, dapat menyebabkan waktu yang tidak menguntungkan dari zona kedua. Dalam metode yang diusulkan, bukannya mengubah waktu zona kedua, bentuk directional arus cadangan estafet akan berubah adaptif dengan lokasi gangguan dan saat ini. Ide mengurangi proteksi arus waktu respon pada arus kesalahan yang lebih tinggi dicapai dengan menggunakan perangkat perlindungan yang universal dengan platform perangkat lunak yang dapat memfasilitasi merancang waktu saat kurva karakteristik yang berbeda bentuk, semua di hardware yang sama. Hasil simulasi menunjukkan efektivitas metode ini.
\end{abstract}

Kata Kunci-Arus Hubung Singkat, Koordinasi Proteksi, Rele Arus Lebih, Rele Jarak.

\section{PENDAhUluan}

$\mathrm{L}$ istrik sekarang ini sudah menjadi kebutuhan sekunder yang penting bagi selruh masyarakat baik di perkotaan maupun pedesaan, bahkan industri-industri juga menggunakan listrik dari PLN untuk kelangsungan proses produksi.

Ketersediaan listrik PLN dari pembangkit-pembangkit di pulau Jawa sudah cukup untuk memenuhi kebutuhan konsumen seluruh pulau Jawa-Bali, namun dalam proses penyaluran listrik tersebut masih banyak muncul kendala/gangguan yang terjadi. Banyak faktor yang dapat menyebabkan terjadinya gangguan sistem tenaga listrik diantaranya adalah gangguan pada sistem Transmisi baik itu Transmisi Teangan Tinggi (SUTT) atau Transmisi Tegangan Extra Tinggi (SUTET), baik gangguan tiga fasa, antar fasa maupun gangguan fasa ke tanah. Penyebabnya bermacam-macam antara lain kelebihan beban, jaringan yang terganggu, dan lain-lain, untuk meminimalisir area gangguan dan mempersingkat waktu terjadinya gangguan maka perlu dipasang peralatan proteksi yang cocok untuk mengatasi gangguan yang muncul. Sistem proteksi bertujuan untuk mengurangi terjadinya gangguan serta mengurangi akibat gangguan tersebut. Sistem proteksi yang digunakan haruslah mampu melindungi sistem transmisi baik SUTT maupun SUTET secara optimal, handal serta memiliki sensifitas tinggi. Banyak peralatan proteksi (dalam hal ini rele pengaman) yang digunakan pada pengaman sistem transmisi diantaranya adalah Rele Arah Arus Lebih / Directional Over Current Relay (DOCR) sebagai backup dari Rele Jarak / Distance Relay. Prinsip Kerja DOCR adalah mendeteksi kelebihan arus serta arah arus akibat beban lebih atau memerintahkan PMT untuk membuka sehingga gangguan dapat dilokalisasi. Sedangakan Rele Jarak adalah untuk mendeteksi impedansi saluran yang terjadi gangguan di sepanjang jalur transmisi, sehingga diketahui zona titik gangguan.

Gangguan yang terjadi kebanyakan pada zona pertama dan zona kedua. Pada pembahasan kali ini lebih fokus pada koordinasi dalam zona kedua karena pada zona kedua lebih sulit dalam koordinasi antara Rele Jarak dan DOCR. Kedua rele (DOCR dan Distance) diaplikasikan untuk mengatasi gangguan hubung singkat pada line SUTT pada daerah GI Rungkut Surabaya agar sistem kelistrikan di daerah tersebut lebih handal. Untuk menganalisa besarnya arus gangguan hubung singkat untuk menentukan setting rele digunakan program simulator yaitu program ETAP.

\section{A. Permasalahan}

Berdasarkan latar belakang masalah yang telah dikemukakan di atas, maka dapat dirumuskan permasalahan sabagai berikut :

1. Kemampuan peralatan dalam menahan arus akibat gangguan hubung singkat.

2. Bagaimana cara mengamankan peralatan dari besarnya arus hubung singkat yang melebihi rating dari device capability peralatan.

3. Bagaimana prinsip kerja Rele Jarak dan DOCR sebagai back-up.

4. Koordinasi rele jarak dan DOCR.

\section{B. Batasan Masalah}

Batasan masalah dalam tugas akhir ini meliputi :

1. Simulasi dan analisa menggunakan software ETAP.

2. Gangguan hubung singkat.

3. Standarisasi perhitungan mengacu pada standard IEC..

4. Program Simulator yang digunakan adalah ETAP versi 12.6, dan digunakan untuk mensimulisasi arus hubung singkat.

5. Semua nilai impedansi real, impedansi shunt, arus magnetisasi, arus pengisian saluran transmisi dan arus beban nol diabaikan. 


\section{Tujuan Penyusunan}

Tujuan yang diharapkan dapat dicapai dari penyusunan tugas akhir ini adalah sebagai berikut :

1. Menghitung dan Menganalisis besarnya arus gangguan pada jaringan SUTT 150kV Gardu Induk Rungkut di area PT. PLN (Persero) APP Surabaya.

2. Menghitung dan menganalisa jarak / zona gangguan untuk rele distance.

3. Menghitung dan menganalisa setting rele DOCR.

4. Menganalisa koordinasi antara rele jarak (distance relay) dan DOCR sebagai back-upnya.

\section{TEORI PENUNJANG}

Ketersediaan listrik terutama pada PLN yang berada di pulau jawa sudah cukup untuk memenuhi kebutuhan masyarakat di area pulau jawa dan bali. Namun, pada proses penyaluran listrik tersebut masih banyak muncul kendala serta gangguan yang terjadi. Penyebabnya bermacam-macam antara lain kelebihan beban, jaringan yang terganggu, dan lain-lain. Untuk meminimalisir gangguan tersebut maka perlu dipasang peralatan proteksi yang cocok untuk mengatasi gangguan tersebut. Peralatan tersebut adalah rele jarak (Distance Relay) dan DOCR (Directional Over Current Relay) sebagai backupnya.

\section{A. $O C R / D O C R$}

Apabila standar yang digunakan untuk penyetingan rele adalah standar IEC (International Electrical Cooperation). Waktu tunda kerja antar CB (pemutus tenaga) adalah 0,4 detik, Standar IEC untuk kurva invers.

Setting berdasarkan standard IEC menurut kurva invers maka didapat persamaan sebagai berikut :

$$
\begin{aligned}
\text { top } & =\frac{k \times r m s}{\left(\left(\frac{I_{\text {fault } 3 \emptyset}}{\mathrm{I}_{\text {set }}}\right)^{\alpha}-1\right)} \\
t m s & =\frac{T}{\beta}
\end{aligned}
$$

dengan $\mathrm{t} 0=1$ detik maka akan didapatkan nilai TMS berdasarkan rumus (2.5) yaitu $t m s=0,1$

- Rele Jarak (Distance Relay)

Proteksi yang paling utama pada saluran transmisi. Rele jarak menggunakan pengukuran tegangan dan arus untuk mendapatkan impedansi saluran yang harus diamankan. Jika impedansi yang terukur didalam batas settingnya, maka rele akan bekerja. Disebut rele jarak, karena impedansi pada saluran besarnya akan sebanding dengan panjang saluran. Oleh karena itu, rele jarak tidak tergantung oleh besarnya arus gangguan yang terjadi, tetapi tergantung pada jarak gangguan yang terjadi

Terhadap rele proteksi. Impedansi yang diukur dapat berupa $\mathrm{Z}, \mathrm{R}$ saja ataupun $\mathrm{X}$ saja, tergantung jenis rele yang dipakai.

Macam - macam rele jarak, yang digunakan untuk proteksi saluran transmisi dapat dilihat pada tabel berikut ini.

TABEL 2.2 Jenis RELE JARAK PROTEKSI SALURAN TRANSMISI

\begin{tabular}{|c|c|c|}
\hline Jenis Rele & Rumus & Diagram \\
\hline \multirow{3}{*}{ Reaktansi } & $\begin{array}{c}T-K_{2} V I \sin \theta+K_{2} l^{2} \\
\left(\alpha-90^{\circ}\right)\end{array}$ & $\begin{array}{r}x \\
\end{array}$ \\
\hline
\end{tabular}

\begin{tabular}{|l|c|c|}
\hline \multirow{2}{*}{ Tahanan } & $\begin{array}{c}T=K_{2} V I \cos \theta+K_{2} I^{2} \\
\left(\alpha=0^{\circ}\right)\end{array}$ \\
\hline Ofiset MHO & $\begin{array}{c}T=K_{1} V^{2} \\
+K_{2} V I \cos (\theta-\alpha)+K_{2} I^{2}\end{array}$ \\
\hline Impedansi & $\begin{array}{c}T=K_{1} V^{2}+K_{2} I^{2} \\
\left(K_{2}=0\right)\end{array}$ \\
\hline MHO & $\begin{array}{c}T=K_{1} V^{2} \\
+K_{2} V I \cos (\theta-\alpha)\end{array}$ \\
\hline Konduktansi & $\begin{array}{c}T=K_{1} V^{2}+K_{2} V I \sin \theta \\
\left(\alpha=90^{\circ}\right)\end{array}$ \\
\hline
\end{tabular}

\section{B. Setting Rele Jarak}

Pengaruh infeed adalah pengaruh penambahan atau pengurangan arus menuju ke titik gangguan terhadap arus yang melewati rele. Hal ini akan menyebabkan pendeteksian lokasi gangguan menjadi salah. Hal-hal yang menyebabkan terjadinya pengaruh infeed adalah:

a. Pembangkit pada ujung saluran yang diamankan. Seperti terlihat pada gambar dibawah ini, maka jika terjadi gangguan di titik F, impedansi dilihat dari rele A adalah :

$$
\begin{aligned}
\mathrm{Z} \text { rA } & =\mathrm{VA} / \mathrm{I} 1=(\mathrm{I} 1 \mathrm{ZAB}+\mathrm{IF} \mathrm{ZBF}) / \mathrm{I} 1 \\
& =\mathrm{ZAB}+(\mathrm{IF} / \mathrm{I} 1) \mathrm{ZBF} \\
& =\mathrm{ZAB}+[(\mathrm{I} 1+\mathrm{I} 2) / \mathrm{I} 1] \mathrm{ZBF} \\
& =\mathrm{ZAB}+(1+\mathrm{I} 2 / \mathrm{I} 1) \mathrm{ZBF}
\end{aligned}
$$

Sehingga rele di A akan merasakan gangguan semakin menjadi lebih pendek.

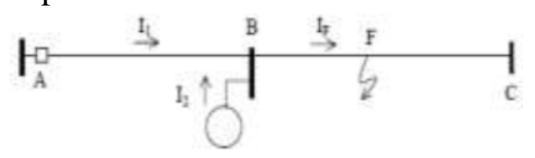

Gambar 2.4 Pengaruh Infeed Akibat Adanya Unit Pembangkit di Ujung Saluran Yang Diproteksi

b. Perubahan saluran transmisi

Perubahan konfigurasi saluran akan mempengaruhi impedansi yang terbaca oleh rele jarak. Sebagai contoh kasus adalah seperti berikut ini :

- Saluran tunggal ke ganda

Impedansi dilihat dari rele A, dengan gangguan di titik $\mathrm{F}$ adalah:

$$
\begin{aligned}
\mathrm{ZrA} & =(\mathrm{I} \mathrm{ZAB}+\mathrm{I} 1 \mathrm{ZBF}) / \mathrm{I}=\mathrm{ZAB}+\mathrm{I} 1 / \mathrm{I} \mathrm{ZBF} \\
& =\mathrm{ZAB}+[(2 \mathrm{l}-\mathrm{x}) / 2 \mathrm{l}] \mathrm{ZBF}
\end{aligned}
$$

Gangguan di dekat bus $\mathrm{B}, \mathrm{x}=0$, maka $\mathrm{k}=1$

Gangguan di bus $\mathrm{C}, \mathrm{x}=1$, maka $\mathrm{k}=1 / 2$

Sehingga gangguan disalah satu transmisi antara B$\mathrm{C}$, impedansi yang dilihat oleh rele A selalu lebih kecil dari sesungguhnya. Akibatnya jangkauan rele lebih panjang

- Saluran ganda ke tunggal 
Impedansi saluran jika dilihat dari rele A, untuk gangguan di titik $\mathrm{F}$ adalah:

$$
\begin{aligned}
\mathrm{ZrA} & =(\mathrm{I} 1 \mathrm{ZAB}+\mathrm{IF} \mathrm{ZBF}) / \mathrm{I} 1 \\
& =\mathrm{ZAB}+\mathrm{IF} / \mathrm{I} 1 \mathrm{ZBF} \\
& =\mathrm{ZAB}+[(\mathrm{I} 1 / \mathrm{I} 2) / \mathrm{I} 1] \mathrm{ZBF}
\end{aligned}
$$

Jika $\mathrm{I} 1=\mathrm{I} 2$, maka $\mathrm{ZrA}=\mathrm{ZAB}+2 \mathrm{ZBF}$

Sehingga gangguan setelah bus $\mathrm{B}$, impedansi dilihat dari rele A akan selalu lebih besar. Akibatnya rele mempunyai jangkauan yang lebih pendek.
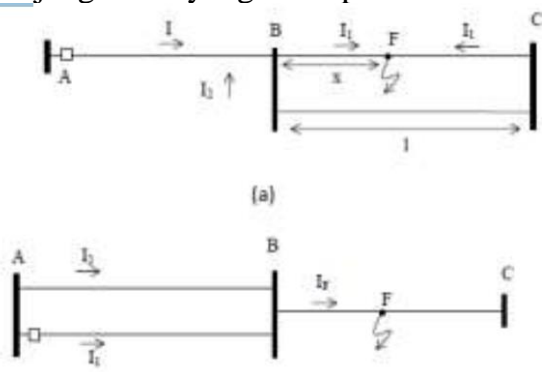

(b)

Gambar 2.5 Pengaruh Infeed Akibat perubahan Saluran a) Saluran tunggal ke ganda b) Saluran ganda ke tunggal

\section{Gangguan-gangguan Pada Sistem Tenaga}

Gangguan pada sistem tenaga terdiri dari dua jenis yaitu :

1. Gangguan Nonsimetris

a. Gangguan hubung singkat satu fasa ke tanah (LGnd)

b. Gangguan hubung singkat dua fasa ke tanah (LLGnd)

c. Gangguan hubung singkat dua fasa (L-L)

2. Gangguan Simetris

a. Gangguan hubung singkat tiga fasa (L-L-L)

b. Gangguan hubung singkat tiga fasa ke tanah (LL-LGnd)

- Hubung Singkat satu fasa ke tanah

Hubung singkat ini disebabkan oleh adanya sambaran petir, isolator pecah, benturan mekanis, satu kawat kena pohon ataupun tali layang-layang dan lain-lain.

Dengan demikian arus gagguan pada fasa a dapat dicari dengan:

$I a f=3 I a 0=3 I a 1=3 I a 2$

Vaf $=Z f . I a f$

Maka,

If $(L-G)=I a=\frac{3 V}{Z 0+Z 1+Z 2+3 Z g}$

- Hubung Singkat dua fasa ke tanah

Hubung singkat ini disebabkan oleh adanya tegangan lebih pada salah satu fasa yang disertai flash over yang terjadi dengan isolator dari fasa disebelahnya. Pada gangguan F dengan sebuah impedansi gangguan $\mathrm{Zf}$ dan impedansi dari saluran ke tanah ZG (yang sama dengan nol atau tak terhingga). Dari persamaan arus di titik gangguan dihasilkan arus gangguan dua fasa ke tanah, yaitu:

$I a f=0=I a 0+I a I+I a 2$

jika Ial dan Ia2 diketahui maka:

$I a 0=-(I a I+I a 2)$

$$
I_{f(L-L-G)}=\frac{\sqrt{3 \cdot V_{L-L}}}{Z_{1}+\frac{Z_{2} \cdot\left(Z_{0}+3 Z_{G}\right)}{Z_{2}+Z_{0}+3 Z_{G}}}
$$

- Hubung Singkat antar fasa Dari gangguan berikut diketahui bahwa:

$$
\begin{aligned}
& I a f=0, I a o=0, I b f=-I c f \\
& \text { Dan, } \\
& V b c=V b-V c=Z f . I b f \\
& I a o=0
\end{aligned}
$$

Sehingga arus urutan dapat dikethui sebagai berikut:

$$
I_{a 1}=-I_{a 2}=\frac{\sqrt{3 \cdot V_{L-L}}}{Z_{1}+Z_{2}+Z_{G}}
$$

- Hubung Singkat tiga fasa ke tanah

Gangguan ini jarang terjadi namun tetap harus mendapat perhatian. penyebab gangguan ini antara lain surja petir yang menyambar ketiga kawat fasa ataupun pohon yang mengenai kawat fasa.

Gangguan ini Merupakan gangguan yang paling besar dari gangguan-gangguan tersebut diatas.

$I a 0=0, I a 2=0$,

$I_{a f}=\frac{V}{\left(Z_{1}+Z_{G}\right)}$

Jika $Z G=0$, Maka arus gangguan tiga fasanya adalah:

$$
I_{f}=I_{f a}=I_{f b}=I_{f c}=I_{a 1}=\frac{V}{z_{1}}
$$

\section{SiSTEM KELISTRIKAN PT. PLN APP SURABAYA}

\section{A. Sistem Kelistrikan Gardu Induk Waru}

Pada gardu induk waru mendapatkan sumber sebesar 3925 MVasc dan menyalurkan ke 2 beban yaitu beban pertama sebesar 11,7 MVA dan beban kedua sebesar 21,5 MVA. Pada gardu induk waru akan juga akan menyuplai gardu induk rungkut dengan 2 buah transmisi yaitu transmisi waru 1 dan transmisi waru 2 . Susunan single line diagram gardu induk waru pada gambar 3.1.

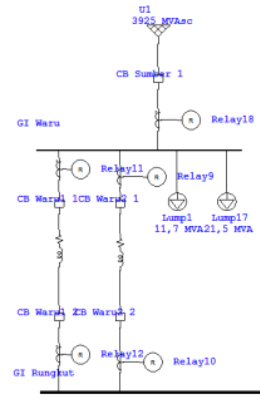

Gambar 3.1 Single line diagram Gardu Induk Waru ke Gardu Induk Rungkut

Pada sistem transmisi yang menghubungkan antara gardu induk waru dengan gardu induk rungkut memiliki beberapa data. Data-data tersebut dapat dilihat pada tabel 3.1

TABEL 3.1 DATA GARDU INDUK WARU.

\begin{tabular}{cccccc}
\hline \hline \multirow{2}{*}{ Nama } & \multicolumn{2}{c}{ Impedansi } & \multirow{2}{*}{ Panjang } & CT & PT \\
\cline { 2 - 3 } Transmisi & $\mathrm{R}$ & $\mathrm{X}$ & Saluran & & \\
\hline WARU 1 & 0,0489 & 0,1909 & $4,76 \mathrm{Km}$ & $2000 / 5$ & $154 / 0,11$ \\
WARU 2 & 0,0489 & 0,1909 & $4,76 \mathrm{Km}$ & $2000 / 5$ & $154 / 0,11$ \\
\hline \hline
\end{tabular}

\section{B. Sistem Kelistrikan Gardu Induk Surabaya Selatan}

Pada gardu induk surabaya selatan mendapatkan sumber sebesar 3925 MVasc dan menyalurkan ke beban yaitu beban dengan daya sebesar 41,2 MVA. Pada gardu induk surabaya selatan akan juga akan menyuplai gardu induk rungkut dengan 2 buah transmisi yaitu transmisi surabaya selatan 1 dan transmisi surabaya selatan 2 . Susunan single line diagram gardu induk surabaya selatan dapat dilihat pada gambar 3.2. 


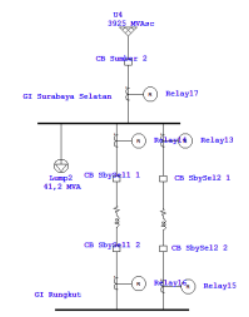

Gambar 3.2 Single line diagram Gardu Induk Surabaya Selatan ke Gardu Induk Rungkut

Pada sistem transmisi yang menghubungkan antara gardu induk surabaya selatan dengan gardu induk rungkut memiliki beberapa data. Data-data tersebut dapat dilihat pada tabel 3.2

\section{Sistem Kelistrikan Gardu Induk Sukolilo}

Pada gardu induk sukolilo menyalurkan ke 3 beban yaitu beban 1 dengan daya sebesar 51,2 MVA, beban 2 dengan daya sebesar 41,7 MVA dan beban 3 dengan daya 32,2 MVA. Pada gardu induk sukolilo selatandisuplai gardu induk rungkut dengan 2 buah transmisi yaitu transmisi sukolilo 1 dan transmisi sukolilo 2. Susunan single line diagram gardu induk sukolilo dapat dilihat pada gambar 3.3.

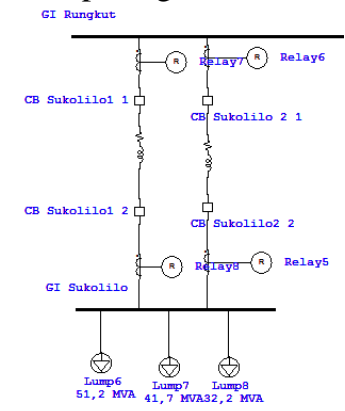

Gambar 3.3 Single line diagram Gardu Induk Rungkut ke Gardu Induk Sukolilo

TABEL 3.1 DATA GARDU INDUK SURABAYA SELATAN.

\begin{tabular}{cccccc}
\hline \hline \multirow{2}{*}{ Nama } & \multicolumn{2}{c}{ Impedansi } & \multirow{2}{*}{ Panjang } & CT & PT \\
\cline { 2 - 3 } Transmisi & $\mathbf{R}$ & $\mathbf{X}$ & Saluran & & \\
\hline SbySel 1 & 0,0387 & 0,287 & $6,775 \mathrm{Km}$ & $2000 / 5$ & $154 / 0,11$ \\
SbySel 2 & 0,0387 & 0,287 & $6,775 \mathrm{Km}$ & $800 / 5$ & $154 / 0,11$ \\
\hline \hline
\end{tabular}

Pada sistem transmisi yang menghubungkan antara gardu induk rungkut dengan gardu induk sukolilo memiliki beberapa data. Data-data tersebut dapat dilihat pada tabel 3.3

\section{Sistem Kelistrikan Gardu Induk Sambikerep}

Pada gardu induk sambikerep menyalurkan ke 2 beban yaitu beban 1 dengan daya sebesar 34,4 MVA, beban 2 dengan daya sebesar 42,7 MVA. Pada gardu induk sambikerep disuplai dari gardu induk rungkut dengan sebuah transmisi yaitu transmisi sambikerep. Susunan single line diagram gardu induk sambikerep dapat dilihat pada gambar 3.4.

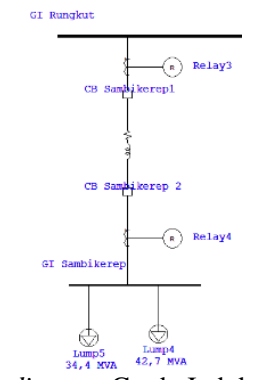

Gambar 3.4 Single line diagram Gardu Induk Rungkut ke Gardu Induk Sambikerep
TABel 3.3 Data Gardu InduK SuKOlio.

\begin{tabular}{|c|c|c|c|c|c|}
\hline \multirow{2}{*}{$\begin{array}{c}\text { Nama } \\
\text { Transmisi }\end{array}$} & \multicolumn{2}{|c|}{ Impedansi } & \multirow{2}{*}{$\begin{array}{l}\text { Panjang } \\
\text { Saluran }\end{array}$} & \multirow{2}{*}{ CT } & \multirow{2}{*}{ PT } \\
\hline & $\mathbf{R}$ & $\mathbf{X}$ & & & \\
\hline SbySel 1 & 0,0387 & 0,287 & $6,775 \mathrm{Km}$ & $2000 / 5$ & $154 / 0,11$ \\
\hline SbySel 2 & 0,0387 & 0,287 & $6,775 \mathrm{Km}$ & $800 / 5$ & $154 / 0,11$ \\
\hline
\end{tabular}

Pada sistem transmisi yang menghubungkan antara gardu induk rungkut dengan gardu induk sambikerep memiliki beberapa data. Data-data tersebut dapat dilihat pada tabel 3.4

\section{E. Sistem Kelistrikan Gardu Induk Hanil Jaya}

Pada gardu induk hanil jaya menyalurkan ke beban yaitu beban dengan daya sebesar 36,67 MVA. Pada gardu induk hanil jaya disuplai dari gardu induk rungkut dengan sebuah transmisi yaitu transmisi sambikerep. Susunan single line diagram gardu induk hanil jaya dapat dilihat pada gambar 3.5.

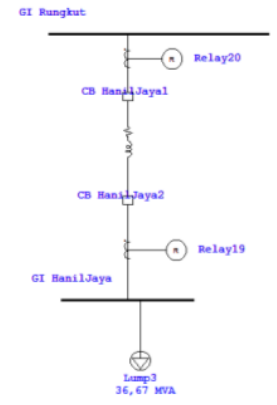

Gambar 3.5 Single line diagram Gardu Induk Rungkut ke Gardu Induk Hanil Jaya

TABEL 3.4 DATA GARDU INDUK SAMBIKEREP.

\begin{tabular}{|c|c|c|c|c|c|}
\hline \multirow{2}{*}{$\begin{array}{c}\text { Nama } \\
\text { Transmisi }\end{array}$} & \multicolumn{2}{|c|}{ Impedansi } & \multirow{2}{*}{$\begin{array}{l}\text { Panjang } \\
\text { Saluran }\end{array}$} & \multirow{2}{*}{ CT } & \multirow{2}{*}{ PT } \\
\hline & $\mathbf{R}$ & $\mathbf{X}$ & & & \\
\hline Sambikerep & 0,0444 & 0,193 & $\begin{array}{c}12,547 \\
\mathrm{Km}\end{array}$ & $2000 / 5$ & $\begin{array}{c}154 / 0,1 \\
1\end{array}$ \\
\hline
\end{tabular}

Pada sistem transmisi yang menghubungkan antara gardu induk rungkut dengan gardu induk Hanil Jaya memiliki beberapa data. Data-data tersebut dapat dilihat pada tabel 3.5

TABEL 3.4 DATA GARDU INDUK HANIL JAYA.

\begin{tabular}{|c|c|c|c|c|c|}
\hline \multirow{2}{*}{$\begin{array}{c}\text { Nama } \\
\text { Transmisi }\end{array}$} & \multicolumn{2}{|c|}{ Impedansi } & \multirow{2}{*}{$\begin{array}{l}\text { Panjang } \\
\text { Saluran }\end{array}$} & \multirow{2}{*}{ CT } & \multirow{2}{*}{ PT } \\
\hline & $\mathbf{R}$ & $\mathbf{X}$ & & & \\
\hline Hanil Jaya & 0,0565 & $\begin{array}{c}0,112 \\
5\end{array}$ & $0,427 \mathrm{Km}$ & $800 / 1$ & $\begin{array}{c}150 / 0,1 \\
1\end{array}$ \\
\hline
\end{tabular}

\section{HASIL SIMULASI DAN ANALISA PT. PLN APP} SURABAYA

\section{A. Perhitungan Setting Distance Rele}

Rele jarak (distance relay) merupakan proteksi yang paling utama pada saluran transmisi. Rele jarak menggunakan pengukuran tegangan dan arus untuk mendapatkan impedansi saluran yang harus diamankan. Jika impedansi yang terukur didalam batas setting, maka rele akan bekerja.

Di sebut rele jarak, karena impedansi pada saluran besarnya akan sebanding dengan panjang saluran. Oleh karena itu, rele jarak tidak tergantung oleh besarnya arus gangguan yang terjadi, tetapi tergantung pada jarak gangguan yang terjadi terhadap rele proteksi. Impedansi yang diukur dapat berupa $\mathrm{Z}, \mathrm{R}$ saja ataupun $\mathrm{X}$ saja, tergantung jenis rele yang dipakai.

Perhitungan Impedansi zona sekunder didapatkan dari rumus : 
Zsekunder $=\frac{\mathrm{CT}}{\mathrm{PT}} \times$ Zprimer

Ada beberapa rumus setting zona yaitu :

Zona $1=80 \%$ x Zsekunder zona 1

Zona $2=80 \%$ x (Zsekunder zona $1+(\mathrm{k} .80 \%$ Zsekunder zona 2))

Zona $3=80 \% \times$ (Zsekunder zona $1+(\mathrm{k}$.

$120 \%$ Zsekunder zona 2))

\section{B. Perhitungan Gangguan Rele Jarak}

Perhitungan Rf, jika gangguan berada di GI Waru (dilihat dari GI Rungkut)

- Gangguan 1Ø-Gnd

-kVf = Tegangan Gangguan

- If-1Ø= Arus gangguan $1 \varnothing$

Maka,

$\operatorname{Zr} 3=\frac{k V f}{\sqrt{3} \cdot \text { If }-1 \varnothing}$

- Gangguan $3 \varnothing$

- $k V f=$ Tegangan gangguan

- If-3Ø= Arus gangguan $3 \varnothing$

Maka,

$\operatorname{Zr} 3=\frac{\sqrt{3} \cdot k V f}{\text { If }-3 \emptyset}$

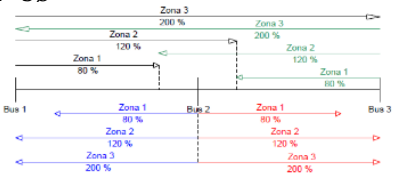

Gambar 4.1 Arah Zona Gangguan

Secara logika teori, jika lokasi gangguan semakin jauh dari sumber, maka impedansi gangguan semakin besar dan akibatnya arus gangguan semakin kecil. Berdasarkan logika tersebut. Terlihat bahwa arus gangguan pada bus 2 lebih kecil bila dibandingkan dengan arus gangguan pada bus $1 \& 3$.

\section{Perhitungan Rele OCR}

\section{- Perhitungan Setting Kerja Rele Arus Lebih (OCR)}

Rele arus lebih (Over current Relay) harus disetting diatas arus beban maksimum dan dibawah arus hubung singkat minimum, artinya pada saat sistem dalam keadaan beban puncak maka rele tidak diharapkan trip oleh karena hal tersebut bukan merupakan sebuah gangguan. Sebaliknya, rele diharapkan mampu mendeteksi arus gangguan sekecil mungkin yang dapat mengganggu kinerja dari sistem.

Dalam perhitungan setting rele ada dua hal yang perlu dilakukan yaitu setting arus dan setting waktu operasi rele. Perhitungan rele arus lebih pada jaringan tenaga listrik dimulai dari rele pada bus penyalur ke beban dalam hal ini bus 2. Pada jaringan konfigurasi ring terdapat dua prosedur dalam melakukan setting waktu rele OCR yaitu prosedur pengurutan waktu searah jarum jam (clockwise) dan pengurutan waktu berlawanan arah jarum jam (anticlockise).

Dari perhitungan sehingga diperoleh setting arus rele arus lebih dari hasil perhitungan adalah sebagai

TABEL 4.11 HASIL SETTING RELE ARUS LEBIH (OCR)

\begin{tabular}{|c|c|c|c|c|c|}
\hline \multirow{2}{*}{ Lokasi } & \multirow{2}{*}{ Rele } & \multirow{2}{*}{$\begin{array}{c}\text { Isc } \\
\text { max } \\
(\mathbf{k A})\end{array}$} & \multicolumn{2}{|c|}{ CT Rasio } & \multirow{2}{*}{ (Perhitungan) } \\
\hline & & & Primer & Sekunder & \\
\hline \multirow{2}{*}{ Waru 1} & 1 & 8,22 & 2000 & 5 & 3744 \\
\hline & 2 & 7,07 & 2000 & 5 & 4712 \\
\hline \multirow{2}{*}{ Waru 2} & 1 & 8,22 & 2000 & 5 & 3744 \\
\hline & 2 & 7,07 & 2000 & 5 & 4712 \\
\hline
\end{tabular}

\begin{tabular}{cccccc} 
Sambikerep & 1 & 14,19 & 2000 & 5 & 8880 \\
& 2 & 14,19 & 2000 & 5 & 8880 \\
Sukolilo 1 & 1 & 11,55 & 1600 & 5 & 6952 \\
Sukolilo 2 & 2 & 11,55 & 1600 & 5 & 6952 \\
& 1 & 11,55 & 2000 & 5 & 6952 \\
Surabaya Selatan 1 & 2 & 11,55 & 2000 & 5 & 6952 \\
\multirow{3}{*}{ Surabaya Selatan 2 } & 2 & 7,38 & 2000 & 5 & 3744 \\
Hanil Jaya & 2 & 7,38 & 2000 & 5 & 4064 \\
& 1 & 31,14 & 800 & 5 & 3744 \\
\hline \hline
\end{tabular}

D. Koordinasi Rele Jarak (Distance Relay) dan Rele Arus lebih (OCR) dengan Combined Curves

Rele yang digunakan dalam sistem ini terdiri dari dua jenis yaitu Rele Distance dan Rele Over Current, dimana rele Distance merupakan main protection atau pengaman utama sedangkan rele over current merupakan backup protection atau pengaman cadangan namun kedua rele tersebut sangat penting untuk pengaman sistem jaringan. Sistem metode dari koordinasi ini adalah combined curves yaitu dengan mengkombinasi dua kurva antara rele jarak dan OCR. Koordinasi kerja dari rele distance dan rele over current ditunjukkan sebagai berikut;

\section{- Koordinasi Rele Jarak dan Relay Arus Lebih pada} GI Waru

Distance R1 = $0 \Omega$; Zona 1; Time operasi : $0 \mathrm{~s}$

OCR waru $1=$ Time operasi : $0,5 \mathrm{~s}$

OCR waru $2=$ Time operasi : $0,5 \mathrm{~s}$

Distance R2=0,3161 $\Omega$; Zona 2; Time operasi : 0,4s OCR waru $1=$ Time operasi : $0,7 \mathrm{~s}$ OCR waru $2=$ Time operasi $: 0,7 \mathrm{~s}$

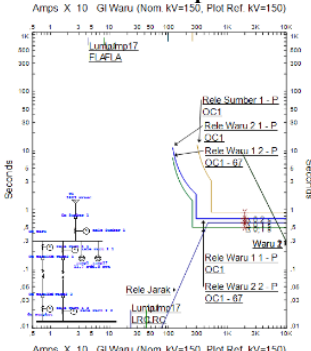

Gambar 4.2 Plot koordinasi rele jarak dan OCR GI Waru

- Koordinasi Rele Jarak dan Rele Arus Lebih pada GI Surabaya Selatan

Distance R3 = $0 \Omega$; Zona 1; Time operasi : $0 \mathrm{~s}$

OCR SbySel $1=$ Time operasi : $0,5 \mathrm{~s}$

OCR SbySel $2=$ Time operasi : $0,5 \mathrm{~s}$

Distance R4=0,2581 $\Omega$; Zona 2; Time operasi : 0,4s

OCR SbySel $1=$ Time operasi : $0,7 \mathrm{~s}$

OCR SbySel $2=$ Time operasi : 0,7 s

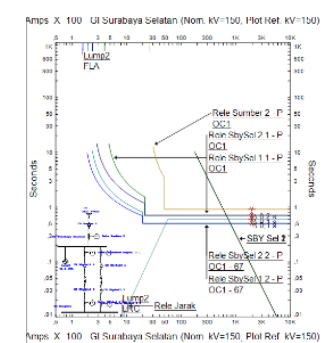

Gambar 4.3 Plot koordinasi rele jarak dan OCR GI Surabaya Selatan

\section{KESIMPULAN/RINGKASAN}

Berdasarkan hasil studi dan analisa koordinasi proteksi rele arus lebih dengan rele jarak menggunakan metode 
combined curves di PT. PLN APP Surabaya, maka dapat diambil beberapa kesimpulan sebagai berikut :

1. Analisa dari rele jarak pada GI Waru memiliki setting rele jarak pada Zona 1 sebesar 0,2144 $\Omega ; \theta=75,63$ dan Zona 2 dengan impedansi terbesar $1,13 \Omega ; \theta=76,77$

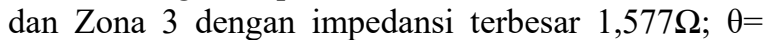
76,85 dengan catatan waktu operasi 0,4 detik pada impedansi $0,316 \Omega$ di zona 2 pada saat hubung singkat 3 fasa dengan back-up rele OCR pada transmisi waru 1 dan waru 2 dengan waktu trip 0,5 dan 0,7. Dengan pada zona kedua di GI Sukolilo, GI Sambikerep serta GI Hanil Jaya memiliki back-up rele arus lebih dengan setting waktu 0,1 dan 0,3 detik.

2. Analisa dari rele jarak pada GI Surabaya Selatan memiliki setting rele jarak pada Zona 1 sebesar $0,246 \Omega ; \theta=82,32$ dan Zona 2 dengan impedansi terbesar $1,16 \Omega ; \quad \theta=78,15$ dan Zona 3 dengan impedansi terbesar $1,608 \Omega ; \theta=77,87$ dengan catatan waktu operasi 0,4 detik pada impedansi $0,316 \Omega$ di zona 2 pada saat hubung singkat 3 fasa dengan backup rele OCR pada transmisi Surabaya Selatan 1 dan Surabaya Selatan 2 dengan waktu trip 0,5 dan 0,7. Dengan pada zona kedua di GI Sukolilo, GI Sambikerep serta GI Hanil Jaya memiliki back-up rele arus lebih dengan setting waktu 0,1 dan 0,3 detik.

\section{UCAPAN TERIMA KASIH}

Dengan ini saya mengucapkan terima kasih kepada :

1. Allah SWT yang masih memperkenankan kepada penulis terlebih lagi atas kesempatan untuk menyelesaikan Tugas Akhir ini.

2. Kedua orang tua tercinta dan keluarga yang telah memberikan dorongan semangat baik moral maupun material.

3. Bapak Dr. Ir. Margo Pujiantara, MT. selaku dosen pembimbing.

4. Bapak Dr. Eng. Ardyono Priyadi, S.T., M..Eng. selaku dosen pembimbing.

5. Seluruh staf pengajar dan karyawan S1 Teknik Elektro - ITS, atas sarana dan prasarana yang diberikan.
6. Teman-Teman LJ angkatan 2014 yang mendukungserta bertukar pikiran.

7. Dan semua pihak-pihak yang tidak bisa saya sebutkan satu persatu. Semoga Allah SWT memberikan limpahan rahmat dan hidayahnya atas segala kebaikan dan semoga

\section{DAFTAR PUSTAKA}

[1] Christopoulos, C, Wright, A. "Electrical Power System Protection", Chapman \& Hall : London : 1993

[2] Das J.C. "Power System Anayisis Short- Circuit Load Flow and Harmonic" Marcel Dekker Inc. Newyork : 2002

[3] Gonen, Turan. "Modern Power System Analysis”. John Wiley \& Son, Inc. 1988

[4] Hewitson, Les. Mark Brown. Ramesh, B. "Practical Power System Protection”. Newnes \& Elsevier : 2004

[5] Jamaah, Akhmad S.T. "Buku Pegangan Kuliah Proteksi Sistem Tenaga" POLINES: 2004

[6] Paithankar, Y.G. Bhide, S.R."Fundamental Of Power System Protection", Prentice-Hall of INDIA. New Delhi.2003.

[7] Saadat, Hadi. 1999. “ Power System Analysis “. New York : The McGraw-Hill Companies.

[8] Sulasno, Ir "Analisa sistem Tenaga Listrik" Satya Wacana : Semarang : 1993

[9] Stevenson, Jr, William, D. “Analisa sistem tenaga listrik”edisi keempat, Erlangga: Jakarta : 1994

[10] Zuhal,"Dasar Teknik Tenaga Listrik dan Elekronika Daya",PT Gramedia Pustaka Utama, Jakarta:1992

[11] PT. PLN (Persero) P3B. "Pelatihan O\&M Relai Proteksi Jaringan" September 2005.

[12] PT. PLN (Persero) P3B “Diklat Kursus Rele Proteksi” Semarang : 2007

[13] http://www.abb.com/global/seitp328.nsf

[14] http://dunia-listrik.blogspot.com. 